EXEMPLARIa Classica

Journal of Classical Philology

14, 2010, pp. 205-209

ISSN 1699-3225

\title{
CALLIRHOE, CONCUBINAGE, AND A CORRUPTION IN CHARITON 2.11.5
}

\author{
STEPHEN M. TRZASKoma \\ The University of New Hampshire \\ s.trzaskoma@unh.edu
}

SuMMARY

The author posits an unnoted textual corruption in Chariton 2.11 .5 (

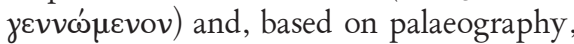
the surrounding context, and an internal parallel, proposes a correction ( $\tau$ ò $\varepsilon \xi \xi \xi \xi \mu \tilde{u}$

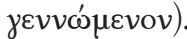

\section{RESUMEN}

El autor señala una desconocida corrup-

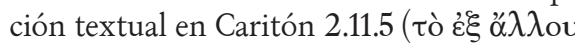

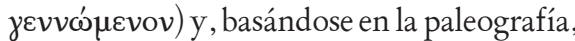
el contexto y un paralelo interno, propone

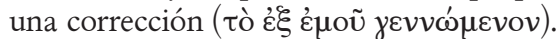

Palabras Clave

Caritón, corrupción textual, concubinato

Chariton, textual corruption, concubinage

Fecha de recepción: 19/08/09

Fecha de aceptación y versión final: 18/12/2009

In the second book of Chariton's Callirhoe, the heroine, who has recently been sold into slavery in the household of Dionysius, discovers that she is pregnant. Plangon, an older slave, determines to use the pregnancy to manipulate Callirhoe into abandoning her fidelity to her husband and sleeping with their master, who has fallen in love with his beautiful new slave. Callirhoe's initial impulse is to abort the child, but she becomes convinced by a dream that her husband Chaereas wishes her to save it. When Plangon learns that Callirhoe plans to remain faithful and bear her child into slavery, the older woman counters by stating flatly that Dionysius will be too jealous to allow Callirhoe to raise the child of a man who is not even around (2.10.1). She disingenuously urges Callirhoe to revert to her initial plan of an abortion. Trapped by circumstances, Callirhoe begs Plangon for a solution, and she obliges: Callirhoe must sleep with Dionysius and pass Chaereas' child off as Dionysius', born prematurely. Callirhoe hesitates and considers killing herself and the child, but an imaginary family council ends in a 2-to-1 vote (Chaereas and the child versus Callirhoe) in favor of the plan to begin a relationship with Dionysius and trick him into believing the child is his.

As a consequence of the council Callirhoe in 2.11 .5 announces to Plangon her general agreement, but raises one further source of hesitation: 


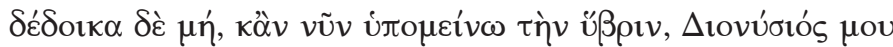

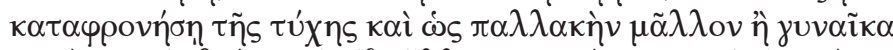

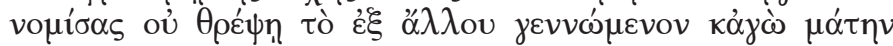

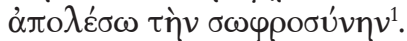

"I'm just afraid that even if I submit and let him have his way with me, Dionysius will look down on me because of my present circumstances. Since he'll think of me more as a concubine than a wife, I fear he won't raise the child born of another man. Then I'll be giving up my fidelity for no reason."

Callirhoe's concern over her legal status-wife or concubine-and its consequences for the fate of her child are of major importance and establish the dominant theme for the beginning of Book 3, where negotiations are carried out between Callirhoe and Dionysius. Plangon, acting as an intermediary, above all seeks to ensure that Callirhoe will be a lawfully

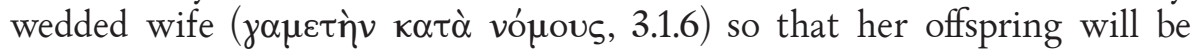
legitimate. Dionysius assures Callirhoe that he will make her his "wedded wife for the production of children in accordance with Greek laws" (3.2.2,

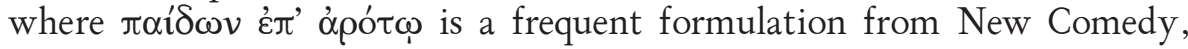
including Men. Sam.726, a play with particular relevance to the problem as I will discuss below).

It is not just the emphasis of this particular portion of the novel. On the contrary, the theme has been carefully prepared in the preceding narrative. The readers know, for instance, that Dionysius feels it "beneath him to share a slave's bed" (2.1.5), but they also know this is before he has seen Callirhoe, and he there assumes that she cannot be both beautiful and a slave. After he has seen her, he speaks of marriage with a slave ( yó $\mu$ ous $\delta$ oú $\lambda \eta_{s}, 2.4 .5$ ), a contradiction in terms. When he learns she is freeborn, he tells her that she will receive the care due the mistress of the house rather than a slave (2.5.12), and he is careful to instruct his servants not to refer to him as her

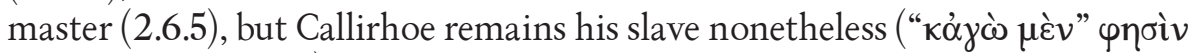

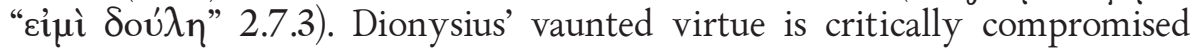
by his desire for Callirhoe. To treat her truly as a free woman would mean letting her leave and taking the risk that his desire would go unfulfilled. So although Dionysius is virtuous enough not to rape her, Callirhoe realizes that his virtue has its limitations. Once she has given in to him, her sole source of power-the hold desire has over him-will be dissipated and she and her child will be at his mercy.

To return to 2.11.5, the difficulty is that the second element of Callirhoe's fear, that Dionysius “won't raise the child born of another man”, makes utterly no sense in the context. The whole point of Plangon's plan and Cal-

${ }^{1}$ Throughout I cite the text and sigla of B. P. Reardon, Chariton Aphrodisiensis. De Callirhoe Narrationes Amatoriae, Munich-Leipzig 2004. All translations are my own. 
lirhoe's agreement is to guarantee that Dionysius will not know the real paternity of the infant. The logic of the passage as transmitted is: If Dionysius treats me as a concubine, then he will not raise another man's child. But the inference here is simply unrelated to the premise.

Callirhoe's concern is plainly made clear in the negotiations. Plangon, purporting to be speaking in Callirhoe's own words ${ }^{2}$, insists that Dionysius give careful and lengthy consideration to what he wants. "I don't want anyone to say to him later, "Are you raising children born from a slave woman and dishonoring your house?' If he is not willing to become a father, let him not become a husband" (3.1.7). The question of paternity, in other words, has no place in any of this, except to the degree that Callirhoe and Plangon work to bind freedom, marriage, and the production of children together as inseparable. Their insistence makes clear that in 2.11.5 Callirhoe is primarily worried that Dionysius will choose not to recognize the legitimacy of her child by treating their relationship as pallakia between master and slave. She presumably supposes that he will either remove the child from the house by killing the child or selling it as a slave. Either outcome would entirely undo the point of Callirhoe's sacrifice and she explicitly acknowledges this:

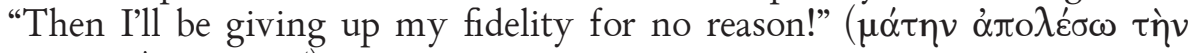

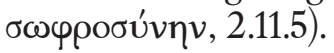

Callirhoe imagines, in other words, being in a situation roughly comparable to that which the concubine Chrysis faces in Menander's Samia ${ }^{3}$. In that play Chrysis and Demeas' child is stillborn, though Demeas does not know this. Chrysis uses his ignorance to raise another newborn-the child Demeas' son got on the neighbors' daughter-as her own. The difficulty is that Demeas has given express instructions that the child by his concubine not be kept in the house. In the preserved portion of the play, Chrysis speaks of the possibility of the baby's ending up being given "to some wet-nurse in a tenement-house" (Sam. 84-5), that is, removed from the house. And when Demeas returns and finds his concubine is raising what he thinks is the child he ordered not to be kept, he complains (129-30) that without realizing it he has had a lawfully wedded mistress ( $\gamma \alpha \mu \varepsilon \tau \dot{\eta} v \dot{\varepsilon} \tau \alpha i \rho \alpha \nu$, a contradiction in terms that sounds much like Dionysius' phrase in Chariton 2.4.5). In other words, if Chrysis really were a gameté, she would have a stronger claim to keep the child. As a hetaira, however, she has none. He views her keeping the child as a valid reason to drive her from his house $(133,352-5)$, and actually does so (382-3). This play was perhaps in Chariton's mind as he cons-

\footnotetext{
${ }^{2}$ And we are meant to believe, I think, that she is. This is a point made well by C. Lucke, "Zum Charitontext auf Papyrus", ZPE 58, 1985, 21-33, at 23 with n. 21.

${ }^{3}$ All references to the Samia are to the edition of D. M. Bain, Menander. Samia, Warminster 1983 (corr. repr. 1985). The similarity between Chariton's novel and the Samia on this matter of plot is mentioned without much elaboration by A. Borgogno, "Menandro in Caritone”, RFIC 99, 1971, 257-63, at 262.
} 
tructed the events in Miletus. His novel and the Samia both have characters who share the name Plangon, though they are of very different natures, and, more importantly, both narratives revolve around the passing off of a son as the child of a man who is not the father and finding a way to ensure that the purported father does not dispose of the child until a happy ending can ensue.

Callirhoe's situation is clear: if she sleeps with Dionysius, she loses her sophrosyne, but she will be able to pass off her child as Dionysius'. If Dionysius marries her, then the child will be raised as Dionysius' heir. If, by contrast, Dionysius has his way with Callirhoe but refuses to legitimize their relationship, he can compel her to give up the child or have the child exposed. But nothing in this scenario will lead automatically to Dionysius' discovery of the true parentage of the baby. Instead, the point is, as the Samia makes clear, that it is perfectly reasonable for a Greek audience to imagine that the father of a child from a concubine would not wish to raise it-especially a man who views sex with a slave as beneath his dignity in the first place.

So what has happened? I propose that a simple corruption has occurred

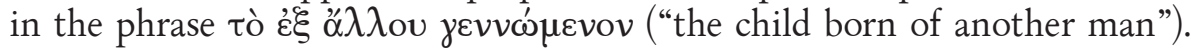
The uncial $\mathrm{M}$ of an original غे $\mu$ ov was mistaken for $\Lambda \Lambda$ and the word read as $\alpha \hat{\alpha} \lambda \mathrm{ov}^{4}$. The scribe's eye betrayed him, but the previous section's content, in which the very question of whether Dionysius will raise another man's child plays a major part, naturalized the error. It certainly has kept modern editors and critics from detecting the corruption ${ }^{5}$. Callirhoe merely expresses the anxiety that if legally she is a concubine instead of a wife, Dionysius will have the ability to treat "the child born from me" however he wishes ${ }^{6}$. The

${ }^{4}$ Elsewhere in Chariton we can see the results of the same confusion in the other direction: in 3.6.6 an original $\dot{\alpha} \lambda \lambda^{\prime}$ or $\dot{\alpha} \lambda \lambda \alpha^{\prime}$ has been transmitted as $\dot{\alpha} \lambda \lambda^{\prime}{ }_{\alpha}^{\alpha} \mu \alpha$. The latter, deleted by Cobet, was obviously derived from the former by mistake when the $\Lambda \Lambda$ was read as a $M$, and both readings were eventually incorporated into the tradition. For a different-and to my mind improbably intricate-explanation of this corruption, see W. Headlam, "Various Conjectures III", Journal of Philology 23, 1895, 266.

${ }^{5} \mathrm{P}$. Michael. $1\left(=\Pi^{3}\right)$ covers this portion of the novel, but the papyrus has a physical gap where these words would have appeared, rendering it irrelevant to the assessment of the current question, except insofar as the presence of the phrase itself in some form is compatible with the space. D. S. Crawford, Papyri Michaelidae, Aberdeen 1955, 1-4, restores the papyrus with the text found in F. If the papyrus originally read غ̇ $\mu$ ov and the text otherwise distributed according to Crawford's reconstruction, the length of the line would drop from 22 letters to 21, a little closer to average for the column (20.3, according to Crawford). But the difference is not great enough to be decisive and 22 is not too long.

${ }^{6}$ The legal particulars are, of course, more complicated than this and made more difficult to interpret because we do not know whether Chariton means us to think of Athenian law as familiar through oratory, contemporary practice in Asia Minor, or Roman law. Luckily, we need not concern ourselves over much. It is at least clear that a Greek audience would have recognized that an alien concubine would have been at a serious disadvantage compared with a lawfully wedded wife when it came to control of her child's fate. In the case of Athenian law after 403/2 BC, the child of a citizen male and an alien pallaké would have automatically 
absolute safety of Callirhoe's child depends upon its mother's status as Dionysius' lawfully wedded wife. Dionysius' knowledge of his status as biological father, or lack thereof, is an irrelevancy.

There is a great deal of verbal repetition between the end of Book 2 and the beginning of 3 , and not just in Plangon's report of Callirhoe's position.

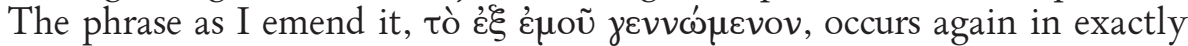
the same form in $3.2 .3^{7}$, where it is uttered by Dionysius. There is, as so often in the relationship between Callirhoe and Dionysius, irony here. When Callirhoe talks of the child born from her, she is simply stating a fact. When Dionysius uses it, he is unaware of how entirely incorrect he is since the child is Chaereas'. The reader, however, can see how very deeply the man has been taken in by Plangon's plot and Callirhoe's carefully thought through legal analysis.

been termed illegitimate. See H. J. Wolff, "Marriage Law and Family Organization in Ancient Athens", Traditio 2, 1944, 43-95 and R. Sealey, "On Lawful Concubinage in Athens", ClAnt 3.1, 1984, 111-33 for treatments of the general questions and further bibliography. Callirhoe assumes the worst-that she will not only be a pallaké but viewed as a slave pallaké, whose children would in any circumstances not only not be legitimate, but not even free.

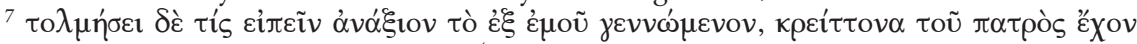
$\tau \grave{v} v \pi \alpha \dot{\pi} \pi$ ov after D’Orville's emendation (the journal's first anonymous reader points out that the same conjecture was perhaps made independently later by J. Jackson, "The Greek Novel-

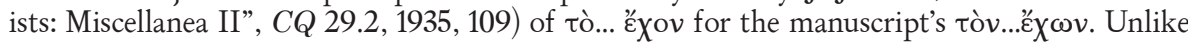
Reardon, W. E. Blake, Charitonis Aphrodisiensis De Chaerea et Callirhoe Amatoriarum Narrationum Libri Octo, Oxford 1938, and G. Molinié, Chariton. De Chaerea et Callirhoe, Paris 1979, do not accept that change into their texts, preferring D'Orville's intermediate emen-

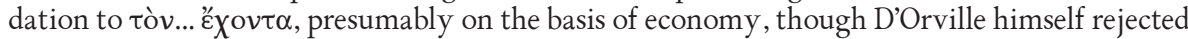

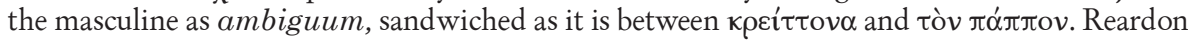
supports the adoption of the neuter through comparison with the phrase at 2.11.5. The journal's second reader draws my attention to the fact that the neuter is generally more idiomatic in

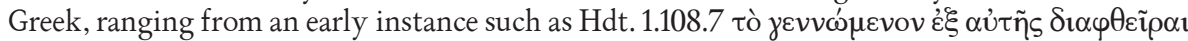

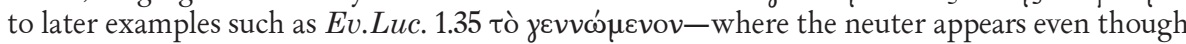
three verses earlier Gabriel has already revealed the coming child will be male. Early Christian

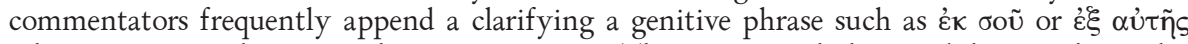
when quoting or discussing the Lucan instance. There is some slight possibility, as the reader communicates, that the prepositional phrase in Chariton is likewise a (mistaken) scribal attempt

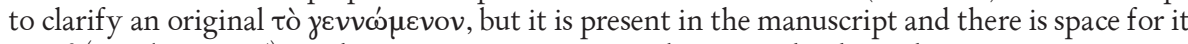
in $\Pi^{3}$ (see above, n. 5), so there seems no reason to advance such a hypothesis in earnest. 
